\title{
Ventilator-induced lung injury: historical perspectives and clinical implications
}

\author{
Nicolas de Prost ${ }^{1}$, Jean-Damien Ricard ${ }^{2,3,4}$, Georges Saumon ${ }^{2}$ and Didier Dreyfuss ${ }^{2,3,4^{*}}$
}

\begin{abstract}
Mechanical ventilation can produce lung physiological and morphological alterations termed ventilator-induced lung injury (VILI). Early experimental studies demonstrated that the main determinant of VILI is lung end-inspiratory volume. The clinical relevance of these experimental findings received resounding confirmation with the results of the acute respiratory distress syndrome (ARDS) Network study, which showed a 22\% reduction in mortality in patients with the acute respiratory distress syndrome through a simple reduction in tidal volume. In contrast, the clinical relevance of low lung volume injury remains debated and the application of high positive end-expiratory pressure levels can contribute to lung overdistension and thus be deleterious. The significance of inflammatory alterations observed during VILI is debated and has not translated into clinical application. This review examines seminal experimental studies that led to our current understanding of VILI and contributed to the current recommendations in the respiratory support of ARDS patients.
\end{abstract}

\section{Introduction}

The prognosis of the acute respiratory distress syndrome (ARDS) has improved dramatically within the past decades, with in-hospital mortality rates ranging from $90 \%$ in the seventies [1] to approximately $30 \%$ in a recent study [2]. Reduction of the tidal volume delivered to mechanically ventilated patients, and thus of the stress applied to their lungs, unambiguously contributed to improving outcomes, as demonstrated by the ARDSnet study, which showed a $22 \%$ higher survival in patients who received lower $(6 \mathrm{~mL} / \mathrm{kg})$ than in those who received larger $(12 \mathrm{~mL} / \mathrm{kg})$ tidal volumes [3]. Interestingly, almost one decade before the ARDSnet study was published, the concept of "permissive hypercapnia" [4] had already led to the use of lower tidal volumes by clinicians and well-conducted observational studies had evidenced significant decrease in the mortality of patients suffering from ARDS [5]. Indeed, compelling physiological evidence had been drawn from experimental studies that had described the deleterious effects of mechanical ventilation using high peak inspiratory pressures on lungs, regrouped under the term ventilatorinduced lung injury (VILI) [6-8]. In addition to this

\footnotetext{
* Correspondence: didier.dreyfuss@lmr.aphp.fr

¿Université Paris-Diderot and PRES Sorbonne Paris Cité, Site Xavier Bichat, 75018 Paris, France

Full list of author information is available at the end of the article
}

"volutrauma," so-called "low-volume" injury associated with the repeated recruitment and derecruitment of distal lung units has been incriminated in the development of VILI and forms the rationale for the use of positive end-expiratory pressure (PEEP) [9-11]. We reviewed seminal experimental studies that led to our current understanding of VILI and contributed to the current recommendations in the respiratory support of ARDS patients.

\section{Historical perspectives}

Only 3 years after the first description of ARDS was made [12], Mead et al. developed the conceptual basis for VILI from the analysis of the mechanical properties of the lungs using a theoretical model of lung elasticity [13]. They suggested that the forces acting on lung parenchyma can be actually much greater than those applied to the airway, and theorized that the pressure tending to expand an atelectatic region at a transpulmonary pressure of $30 \mathrm{~cm} \mathrm{H}_{2} \mathrm{O}$ surrounded by fully expanded lung would be approximately $140 \mathrm{~cm} \mathrm{H}_{2} \mathrm{O}$ [13]. In a visionary statement, the authors concluded that "mechanical ventilation, by applying high transpulmonary pressures to heterogeneously expanded lungs, could contribute to the development of lung hemorrhage and hyaline membranes." In 1974, Webb and Tierney demonstrated for the first time that mechanical

\section{SpringerOpen ${ }^{\odot}$}

(C) 2011 de Prost et al; licensee Springer. This is an Open Access article distributed under the terms of the Creative Commons Attribution License (http://creativecommons.org/licenses/by/2.0), which permits unrestricted use, distribution, and reproduction in any medium, provided the original work is properly cited. 
ventilation could generate lung lesions in intact animals [6]. Rats ventilated with peak inspiratory pressures of 30 or $45 \mathrm{~cm} \mathrm{H}_{2} \mathrm{O}$ developed pulmonary edema within 60 and $20 \mathrm{~min}$, respectively. Interestingly enough, when a 10- $\mathrm{cm} \mathrm{H}_{2} \mathrm{O}$ PEEP was applied and the level of endinspiratory pressure kept constant, the amount of lung edema was lessened [6]. Although the authors suggested that low tidal ventilation should be used, they recently mentioned that "this article seemed to interest few clinicians or investigators for a decade or more, perhaps because a similar degree of injury in patients was not apparent" and acknowledged that "in retrospect, it seems almost irresponsible that we didn't publicize our concerns that such ventilator patterns might be harmful to humans" [14]. Since this seminal publication, our knowledge of VILI has considerably increased [15].

In early publications, the development of pulmonary edema during mechanical ventilation was ascribed to increased lung microvascular pressure, resulting from high lung volume ventilation and surfactant depletion $[6,7,16]$. As a matter of fact, Parker et al. showed that mean lung microvascular pressure increased by $12.5 \mathrm{~cm}$ $\mathrm{H}_{2} \mathrm{O}$ during ventilation of open-chest dogs at $64 \mathrm{~cm}$ $\mathrm{H}_{2} \mathrm{O}$ positive inspiratory pressure [16]. Indeed, it has been demonstrated that lung inflation decreases interstitial pressure (thus, increases transmural pressure) around extra-alveolar vessels because of the interdependence phenomenon and around alveolar vessels because of surfactant inactivation. Inflating lungs dilates extraalveolar vessels [17] and during inflation from low transpulmonary pressure, the increase in vessel diameter is such that an effective outward-acting pressure in excess of pleural pressure (1 to $2 \mathrm{~cm} \mathrm{H}_{2} \mathrm{O}$ for each centimeter of water increase in transpulmonary pressure) expands these vessels [18]. Surfactant is inactivated commensurately with the magnitude of tidal volume and duration of ventilation during ventilation of excised lungs [19-21]. It was demonstrated that the increase in alveolar surface tension resulting from surfactant inactivation leads to increased filtration through alveolar microvessels [22-24]. However, the magnitude of microvascular pressure changes during lung inflation is modest and insufficient to explain the occurrence of severe pulmonary edema during mechanical ventilation with a high tidal volume. In addition to pressure changes, alterations of alveolo-capillary barrier permeability are involved in the development of pulmonary edema during highvolume ventilation of intact animals and are the most important responsible for VILI. The increase in alveolar epithelial permeability to small hydrophilic solutes has been studied by Egan during static inflation of fluidfilled in situ sheep lobes $[25,26]$. The equivalent-pore radius (an index of epithelial permeability) increased from approximately $1 \mathrm{~nm}$ at $20 \mathrm{~cm} \mathrm{H}_{2} \mathrm{O}$ inflating pressure to $5 \mathrm{~nm}$ at $40 \mathrm{~cm} \mathrm{H}_{2} \mathrm{O}$ alveolar pressure. Albumin diffused freely across the epithelium at the highest pressures, indicating the presence of large leaks. Such permeability increases persisted or even increased after cessation of inflation, implying that epithelial injury was irreversible. Unexpectedly, Parker et al. demonstrated in isolated blood-perfused dog lobes that microvascular permeability alterations, as assessed by increased capillary filtration coefficient, also occurred during high peak pressure ventilation ( $>45 \mathrm{~cm} \mathrm{H}_{2} \mathrm{O}$ ) [7]. It was subsequently demonstrated that, within minutes after the onset of ventilation, rats ventilated with $45 \mathrm{~cm} \mathrm{H}_{2} \mathrm{O}$ peak pressures exhibited not only macroscopic pulmonary edema (Figure 1) but also a dramatic increase in microvascular permeability assessed by the distribution space of intravenously injected ${ }^{125}$ I-labeled albumin (Figure 2) [8]. Electron microscopy studies consistently revealed widespread disruption of epithelial cells leading to denudation of basement membranes and the presence of many gaps in the capillary endothelium (Figure 3A, B) [8]. Such findings demonstrated that high-volume mechanical ventilation leads to pulmonary edema of the permeability type.

The increase in transmural microvascular pressure, even if modest, contributes to the severity of pulmonary edema, which may be fulminating during VILI, because any increase in the driving force will have a dramatic effect on edema formation in the face of an altered microvascular permeability [27].

\section{Mechanical determinants of ventilator-induced lung injury}

Role of end-inspiratory lung volume

The term "barotrauma" was formerly used by clinicians to describe the lung damage attributable to ventilation with high peak pressures; the most common form is pneumothorax [28]. However, it was proposed that this term should be replaced by the term "volutrauma." To discriminate between the effects of lung distension and airway pressure, rats ventilated with identical $(45 \mathrm{~cm}$ $\mathrm{H}_{2} \mathrm{O}$ ) peak pressures using high or low volume (generated by limiting thoracoabdominal excursions by strapping) ventilation were compared [29]. The rats subjected to high volume-high pressure ventilation developed pulmonary edema whereas those subjected to low volumehigh pressure ventilation did not. That high pressures are not a prerequisite for the development of pulmonary edema was further confirmed by ventilating rats with high tidal volume but negative airway pressures by means of an iron lung (Figure 4) [29]. Those findings have been replicated in rabbits [30] and in lambs [31]. The question of whether pulmonary edema during mechanical ventilation occurs above a threshold volume was addressed by Carlton et al. in a lamb model of VILI 


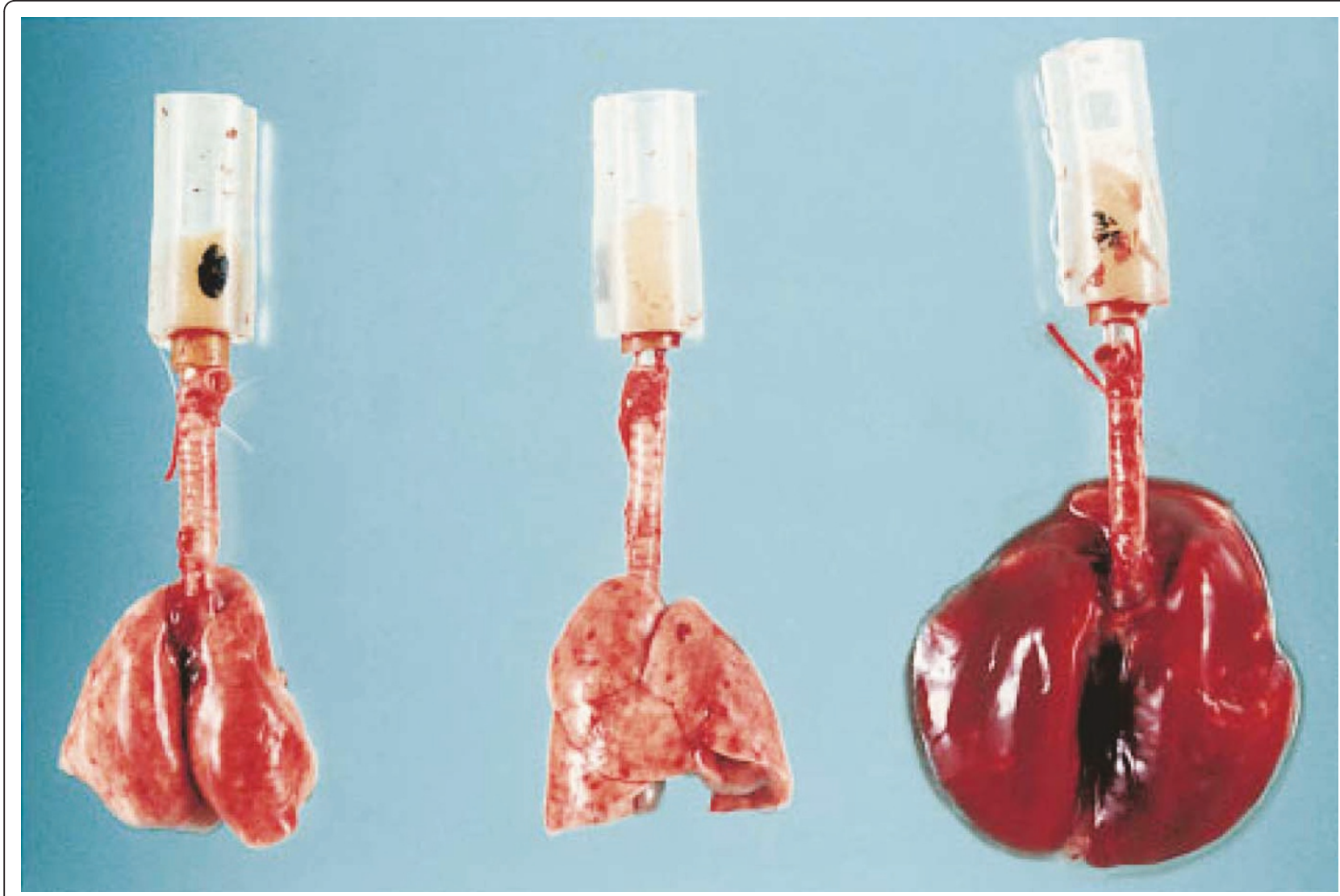

Figure 1 Macroscopic aspect of rat lungs after mechanical ventilation at $45 \mathrm{~cm} \mathrm{H}_{2} \mathrm{O}$ peak airway pressure. Left: normal lungs; middle: after $5 \mathrm{~min}$ of high airway pressure mechanical ventilation. Note the focal zones of atelectasis (in particular at the left lung apex); right: after 20 min, the lungs were markedly enlarged and congestive; edema fluid fills the tracheal cannula. Used with permission. From Dreyfuss et al. [15].

[31]. Gradually increasing tidal volumes, corresponding to end-inspiratory pressures of $16,33,43$, and $61 \mathrm{~cm}$ $\mathrm{H}_{2} \mathrm{O}$, these authors showed that lung lymph flow and protein concentration were increased only when the highest tidal volume $(57 \mathrm{~mL} / \mathrm{kg})$ and pressure level $(61$ $\mathrm{cm} \mathrm{H}_{2} \mathrm{O}$ ) were reached, suggesting that microvascular alterations in response to overinflation occurred beyond a volume/pressure threshold rather than gradually [31]. Those findings were confirmed using scintigraphic methods that allow for the assessment of simultaneous changes in alveolar and microvascular permeability during lung inflation in rats with previously intact lungs [32]. Interestingly, the same end-inspiratory pressure threshold (between 20 and $25 \mathrm{~cm} \mathrm{H}_{2} \mathrm{O}$, corresponding to tidal volumes of $13.7 \pm 4.69$ and $22.2 \pm 2.12 \mathrm{~mL} / \mathrm{kg}$ ) was observed for epithelial and endothelial permeability changes (Figure 5).

Increasing end-inspiratory volume by increasing the functional residual capacity (i.e., applying PEEP) may cause lung injury independently of tidal volume [33]. As a result, PEEP application when tidal volume is kept constant increases lung end-inspiratory volume and can be deleterious. For instance, rats ventilated with a tidal volume within the physiologic range developed pulmonary edema when a $15 \mathrm{~cm} \mathrm{H}_{2} \mathrm{O}$ but not a $10 \mathrm{~cm} \mathrm{H}_{2} \mathrm{O}$ PEEP was applied [33]. Likewise, there was no effect of doubling tidal volume in animals ventilated with ZEEP, but it resulted in pulmonary edema when a $10 \mathrm{~cm} \mathrm{H}_{2} \mathrm{O}$ PEEP was used (Figure 6) [33].

\section{Low lung-volume injury and beneficial effects of PEEP}

The application of PEEP results in less severe lung lesions when end-inspiratory volume is kept constant. This might be related to a reduction of tidal volume and the stabilization of terminal units. Webb and Tierney showed that at $45 \mathrm{~cm} \mathrm{H}_{2} \mathrm{O}$ teleinspiratory pressure, edema was less severe when a $10 \mathrm{~cm} \mathrm{H}_{2} \mathrm{O}$ PEEP was applied and attributed this effect to the preservation of surfactant activity [6]. It was later confirmed that for a same end-inspiratory pressure, rats ventilated with zero end-expiratory pressure exhibited larger amounts of lung edema, as determined by extravascular lung water measurement, than those ventilated with PEEP. However, in the presence of PEEP edema remained confined 

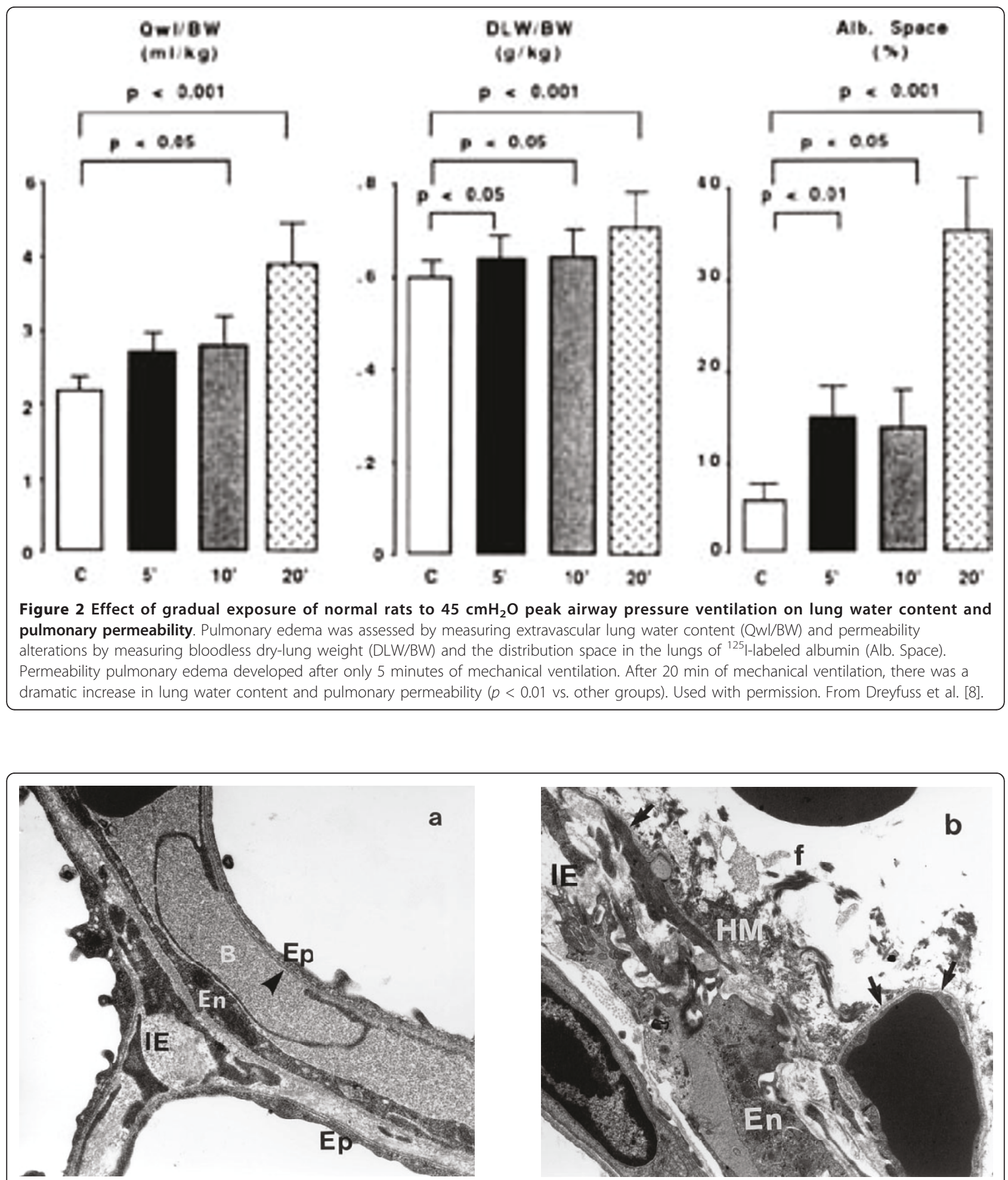

Figure 3 Changes in the ultrastructural appearance of the blood-air barrier after $5 \mathrm{~min}$ (A) and $20 \mathrm{~min}$ (B) mechanical ventilation of a closed-chest rat at $45 \mathrm{~cm} \mathrm{H} \mathrm{H}_{2} \mathrm{O}$ peak airway pressure. (A) The thin part of an endothelial cell (En) is detached from the basement membrane (arrowhead) forming a bleb. (B) Very severe changes in the alveolar-capillary barrier resulting in diffuse alveolar damage. The epithelial layer is totally destroyed (upper right quadrant) leading to denudation of the basement membrane (arrows). Hyaline membranes (HM), composed of cell debris and fibrin ( $f$ ), occupy the alveolar space. IE, interstitial edema. Used with permission. From Dreyfuss et al. [15] (panel A) and [8] (panel B). 


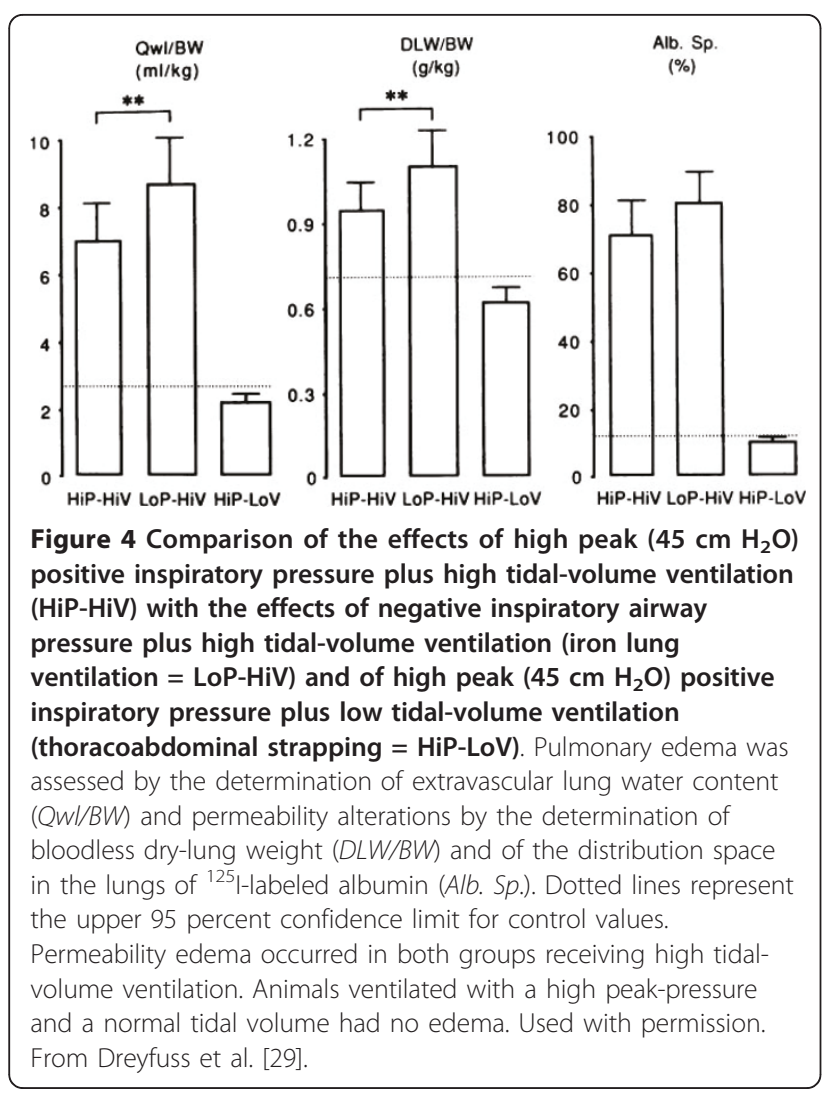

to the interstitium, whereas there was alveolar flooding in its absence [29]. The application of PEEP during VILI development was associated with a preservation of the integrity of the alveolar epithelium and the only ultrastructural abnormalities observed were endothelial

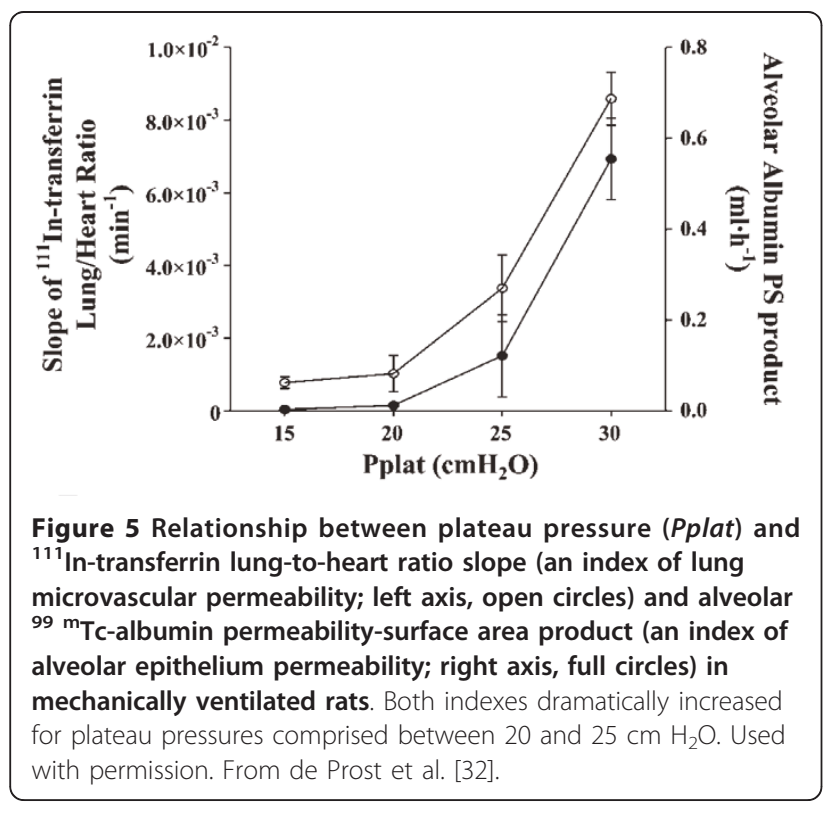

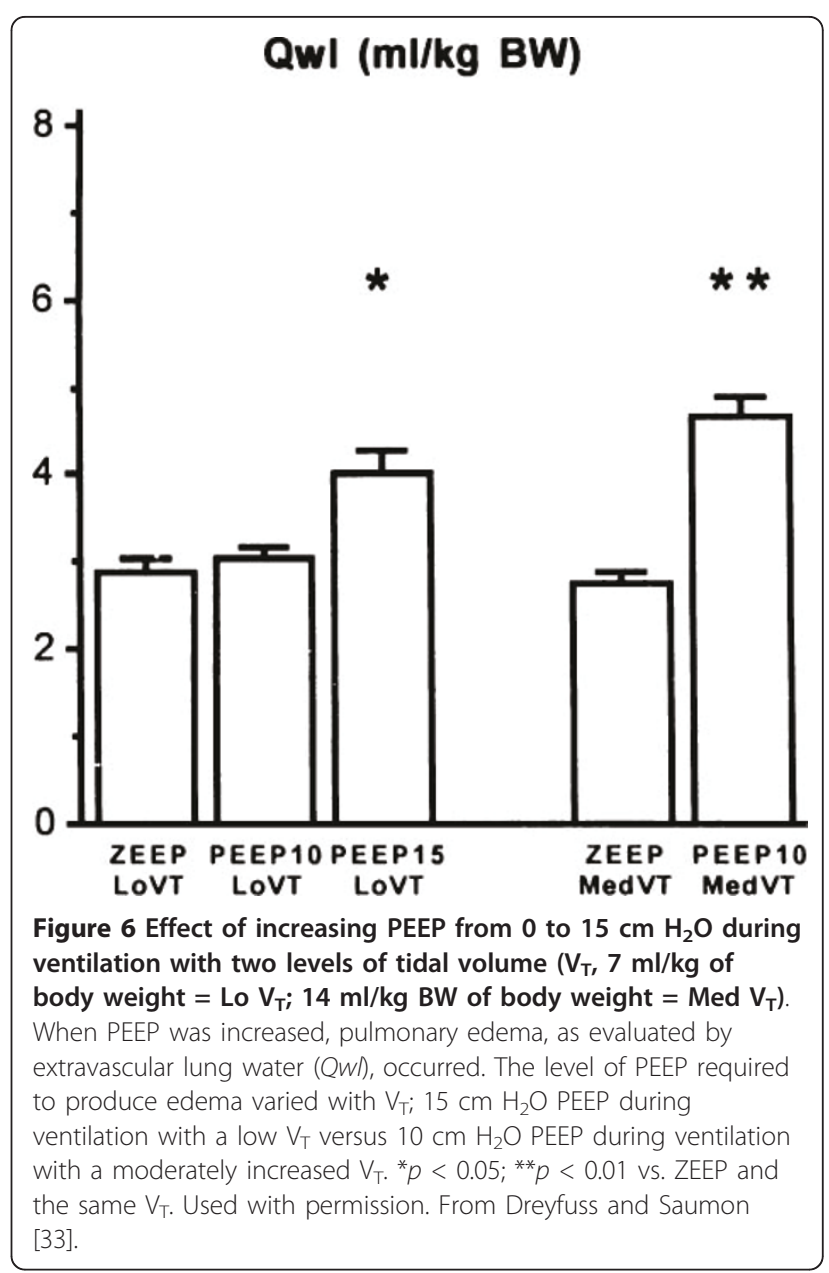

blebbing and interstitial edema [29]. This beneficial effect of PEEP might be related to the reduction of cyclic recruitment-derecruitment of lung units, which causes the abrasion of the epithelial airspace lining by interfacial forces $[10,11]$. These phenomena of repeated opening and closing of distal lung units have been theorized to provide an explanation why large cyclic changes in lung volume promote the development of edema. Indeed, for an identical increase in mean airway pressure, ventilation of hydrochloric acid-injured dog lungs with a large tidal volume and a low PEEP resulted in more severe edema than did ventilation with a small tidal volume and a high PEEP [34]. The effect of the amplitude of tidal volume on alveolar epithelium protein permeability, end-inspiratory pressures being kept constant by manipulating PEEP level, was further confirmed in rats using noninvasive scintigraphic techniques [35]. The alveolar albumin permeability-surface area product, measured from the clearance of an intra-tracheally instilled ${ }^{99} \mathrm{~m}^{\mathrm{T}} \mathrm{T}$-labeled albumin solution, dramatically increased, and in a dose-dependent manner, when $\mathrm{V}_{\mathrm{T}}$ was increased from 8 to 24 and $29 \mathrm{~mL} / \mathrm{kg}$ [35]. Finally, 
the decrease in cardiac output secondary to the increase in intrathoracic pressures has been demonstrated to account for a part of the PEEP-induced reduction in pulmonary edema [33]. All in all, the beneficial effects of PEEP during high-volume ventilation (i.e., reductions in both the amount of edema and the severity of cell damage) involve a combination of hemodynamic alterations, shear stress reduction, and surfactant modifications.

\section{Influence of previous injury on the susceptibility to VILI}

This is an important aspect of VILI. In fact, original descriptions of VILI were made on normal lungs subjected to very high distending pressure $[6-8,36]$. It is fundamental to assess whether a preexisting injury may sensitize lungs to the deleterious effects of mechanical ventilation. This possibility was suggested by the calculations made by Mead and colleagues [13], who showed that the pressure tending to expand an atelectatic region surrounded by a fully expanded lung is approximately $140 \mathrm{~cm} \mathrm{H}_{2} \mathrm{O}$ at a transpulmonary pressure of $30 \mathrm{~cm}$ $\mathrm{H}_{2} \mathrm{O}$. Several studies evaluated the susceptibility to VILI of previously injured lungs. For instance Parker's group showed that neither low doses of oleic acid nor $25 \mathrm{~cm}$ $\mathrm{H}_{2} \mathrm{O}$ peak inspiratory pressure mechanical ventilation increased filtration coefficient and wet-to-dry ratio in an isolated-perfused rabbit lung model [37]. However, the combination of both injuries did so and was thus more deleterious than either one alone. These observations were later confirmed and expanded. The effects of different degrees of lung distention were studied in rats whose lungs had been injured by $\alpha$-naphthylthiourea (ANTU) [38]. Low doses of ANTU were used to create mild lung injury. As a matter of fact, ANTU infusion alone caused moderate interstitial pulmonary edema of the permeability type. When used in the absence of ANTU administration, mechanical ventilation resulted in a permeability edema, which was more severe as tidal volume was increased. The combination of both injuries showed that they were not simply additive but synergistic. Indeed, the severity of edema was more important that the simple summation of the effect of either one alone (Figure 7). Interestingly, alterations of lung mechanical properties induced by ANTU administration were predictive of this synergism [38]. This finding underlines the importance of an adequate examination of the pressure-volume curve during VILI.

\section{Interest of the pressure-volume curve Lung compliance and upper inflection point}

Because of the heterogeneity of lung volume reduction, ventilation will be redistributed toward the more compliant zones, which may favor their overinflation. In the absence of an accurate tool for measuring ventilatable

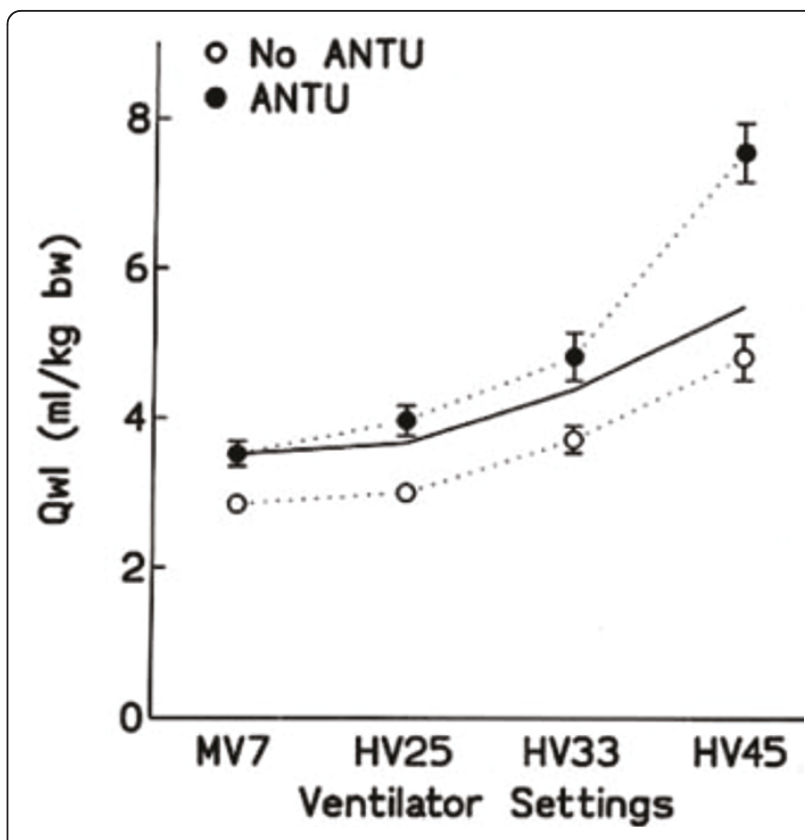

Figure 7 Interaction between previous lung alterations and mechanical ventilation on pulmonary edema. Effect of previous toxic lung injury. Extravascular lung water (QW/) after mechanical ventilation in normal rats (open circles) and in rats with mild lung injury produced by $\alpha$-naphthylthiourea (ANTU) (closed circles). Tidal volume $\left(V_{T}\right)$ varied from 7 to $45 \mathrm{ml} / \mathrm{kg}$ body weight. The solid line represents the $\mathrm{Qwl}$ value expected for the aggravating effect of ANTU on edema caused by ventilation, assuming additivity. ANTU did not potentiate the effect of ventilation with $V_{T}$ up to $33 \mathrm{ml} / \mathrm{kg}$ body weight. In contrast, $V_{T} 45 \mathrm{ml} / \mathrm{kg}$ body weight produced an increase in edema that greatly exceeded additivity, indicating synergy between the two insults. Used with permission. From Dreyfuss et al. [38].

lung volume, analysis of the pressure-volume (PV) curve may help understand how pre-existing lung injury interacts with ventilator-induced injury. The decrease in compliance associated with lung edema is related to the reduction in the ventilatable lung volume, the so-called "baby lung" observed during ARDS $[39,40]$. In addition, the upper inflection point (UIP) of the PV curve represents the lung volume at which lung compliance begins to diminish and thus is a surrogate of the beginning of overinflation $[41,42]$. Both respiratory system compliance and the position of the UIP may allow for a better understanding of the consequences of high-volume ventilation. Indeed, the amount of pulmonary edema produced by high-volume ventilation in animals given ANTU [38] was inversely proportional to the respiratory system compliance measured during the first breaths, i.e., before any damage due to ventilation had occurred. In other words, the lower the lung compliance after ANTU infusion, the higher the amount of edema during VILI. Similarly, animals with an UIP occurring at lower pressures (indicating an earlier onset of overdistension) 
developed more edema than those with an UIP occurring at higher pressures. This suggests that reduced lung distensibility predisposes to the noxious effects of high volume ventilation.

This concept was further strengthened during experimental reduction of the ventilatable lung volume by instillation of a viscous liquid in distal airways of rats. As with ANTU, the higher the compliance and volume of the UIP after instillation of the liquid but before the onset of high-volume ventilation, the lower was the amount of edema observed after high peak pressure ventilation, suggesting that the UIP is a marker of the amount of ventilatable lung volume, and a predictor of the development of edema during mechanical ventilation [43].

Lower inflection point (LIP): can lung parenchyma be altered by repetitive opening and closure of distal airway units?

The lower inflection point (LIP) of the PV curve corresponds to the volume and pressure at which there is the greatest increase in the compliance of the respiratory system. This point may reflect the reexpansion of atelectatic parenchyma and has been considered to indicate the minimal pressure required to recruit collapsed alveoli, as setting the PEEP level according to this point has been shown to improve oxygenation of ARDS patients $[44,45]$. Sykes' group showed that setting PEEP above the LIP in rabbit models of surfactant depletion (after repeated alveolar lavage) improved oxygenation and lessened lung damage compared with lower PEEP levels $[9,46]$. This lessening of pathological alterations was observed even with ventilator settings that achieved identical mean airway pressures in the low and high PEEP groups [46]. These observations were confirmed in isolated surfactant-depleted nonperfused lungs [11]. In contrast, those findings could not be replicated by Sykes' group in a rabbit model of hydrochloric acid instillation [47], suggesting that this strategy for setting PEEP based on the LIP of the pressure-volume curve is only beneficial in conditions associated with major alveolar instabilities, such as encountered during surfactant depletion. Moreover, Lichtwarck-Aschoff et al. showed that when PEEP was set at the LIP in surfactant-depleted piglets, there was a decrease in compliance during tidal volume insufflation, which indicated overinflation [48]. The authors concluded that the PEEP level that allows compliance to remain constant during the full tidal volume insufflation cannot be routinely derived from analysis of the pressure-volume curve.

These discrepancies are not trivial because they underlie the concept of "protective ventilation" during acute lung injury. Indeed, whereas numerous experimental studies have demonstrated that lung overinflation-regional or global-leads to VILI [6-8,36,49], the genesis of lesions at low lung volume is much more debated [50]. Such lesions could result from repetitive opening and collapse of distal airways/alveoli, a mechanism termed "atelectrauma" [51]. However, as explained earlier, this phenomenon might be limited to certain particular settings (e.g., surfactant depletion) and might not be relevant to edematous lungs. For instance, Hubmayr's group challenged this concept using both elegant experimental settings and insightful mathematical models [50,52]. They concluded that distal airways do not close and open during ventilation when PEEP is set below the LIP but, instead, demonstrated that the LIP reflects the movement of liquid or foam in the airways: when a liquid column is present in the airways, it opposes a marked resistance to the airflow; after a certain pressure threshold the liquid is propelled into the alveoli where it can distribute in a much larger volume than in the airways. As a result, there is an abrupt gain in volume at constant (or even decreased) pressure that translates into a prominent knee on the PV curve. In such circumstances, no epithelial lesion is generated and the LIP may be considered as an artifact. There is no doubt that a certain level of PEEP is beneficial during VILI $[6,9,29,46]$, but there is no firm demonstration that this level must necessarily be "high" rather than "low" and may be deduced from the presence of a LIP on the PV curve. Interestingly, this controversy about the respective contribution of overall lung distension and of cyclic recruitment-derecruitment has its exact counterpart for the management of ARDS: it is beyond doubt that tidal volume reduction saves lives [3], whereas the improvement of prognosis with higher PEEP is highly disputable $[2,53,54]$. This clinical controversy will be addressed elsewhere in this article.

\section{The biotrauma hypothesis}

Several studies have shown that protracted mechanical ventilation using high peak pressures led to lung infiltration with neutrophils $[49,55]$. Moreover, neutrophil depletion was associated with better gas exchange and less lung injury in a rabbit model of surfactant depletion [56], suggesting that the inflammatory reaction per se could be deleterious. On the other hand, early studies had evidenced that mechanical ventilation could have deleterious systemic effects. For instance, Kolobow et al. demonstrated that sheep ventilated with $50 \mathrm{~cm} \mathrm{H}_{2} \mathrm{O}$ peak pressure, corresponding to tidal volumes of 50 to $70 \mathrm{~mL} / \mathrm{kg}$, died from multiple organ dysfunction within $48 \mathrm{~h}$ [36]. The biotrauma hypothesis, i.e., lung tissue stretching might result in lung damage solely through the release of inflammatory mediators and leukocyte recruitment, has been put forward to provide an explanation why most patients with ARDS die from multiple organ failure rather than hypoxemia. Tremblay et al. 
[57] showed in unperfused rat lungs that high tidal volume ventilation $(40 \mathrm{~mL} / \mathrm{kg})$ with zero end-expiratory pressure resulted in dramatic increases in the lung lavage levels of tumor necrosis factor- $\alpha$ (TNF- $\alpha$ ), interleukin-1 $\beta$ (IL-1 $\beta$ ), interleukin-6, and macrophage inflammatory protein-2, compared with controls (Figure 8 ), suggesting that mechanical ventilation can influence the inflammatory/anti-inflammatory balance in the lungs. However, using the same model of unperfused rat lungs, others found only slightly higher IL- $1 \beta$ and MIP2 bronchoalveolar lavage fluid concentration in rats ventilated with $42 \mathrm{~mL} / \mathrm{kg}$ tidal volume than in those ventilated with $7 \mathrm{~mL} / \mathrm{kg}$ tidal volume [58,59] (Figure 9). Moreover, there was no difference in TNF- $\alpha$ lung level between both ventilator strategies. The authors concluded that ventilator strategies that injure lungs do not necessarily result in primary production of proinflammatory cytokines in the lungs [59]. The two-hit hypothesis has been put forward to reconcile these discrepant findings. Injurious mechanical ventilation may not be sufficient per se to promote intense lung proinflammatory cytokine secretion but will do so in combination with another aggression [60,61]. For instance, hemorrhagic shock and resuscitation and high PIP ventilation in rats interact to increase lung and systemic release of proinflammatory mediators (Figure 10). The biotrauma hypothesis seemed supported by the finding that ARDS patients ventilated with a protective strategy (i.e., tidal volume of $7 \mathrm{~mL} / \mathrm{kg}$ and PEEP of $15 \mathrm{~cm} \mathrm{H}_{2} \mathrm{O}$ determined from analysis of the PV curve) exhibited lower bronchoalveolar lavage fluid and plasma concentrations of inflammatory mediators than patients ventilated with a

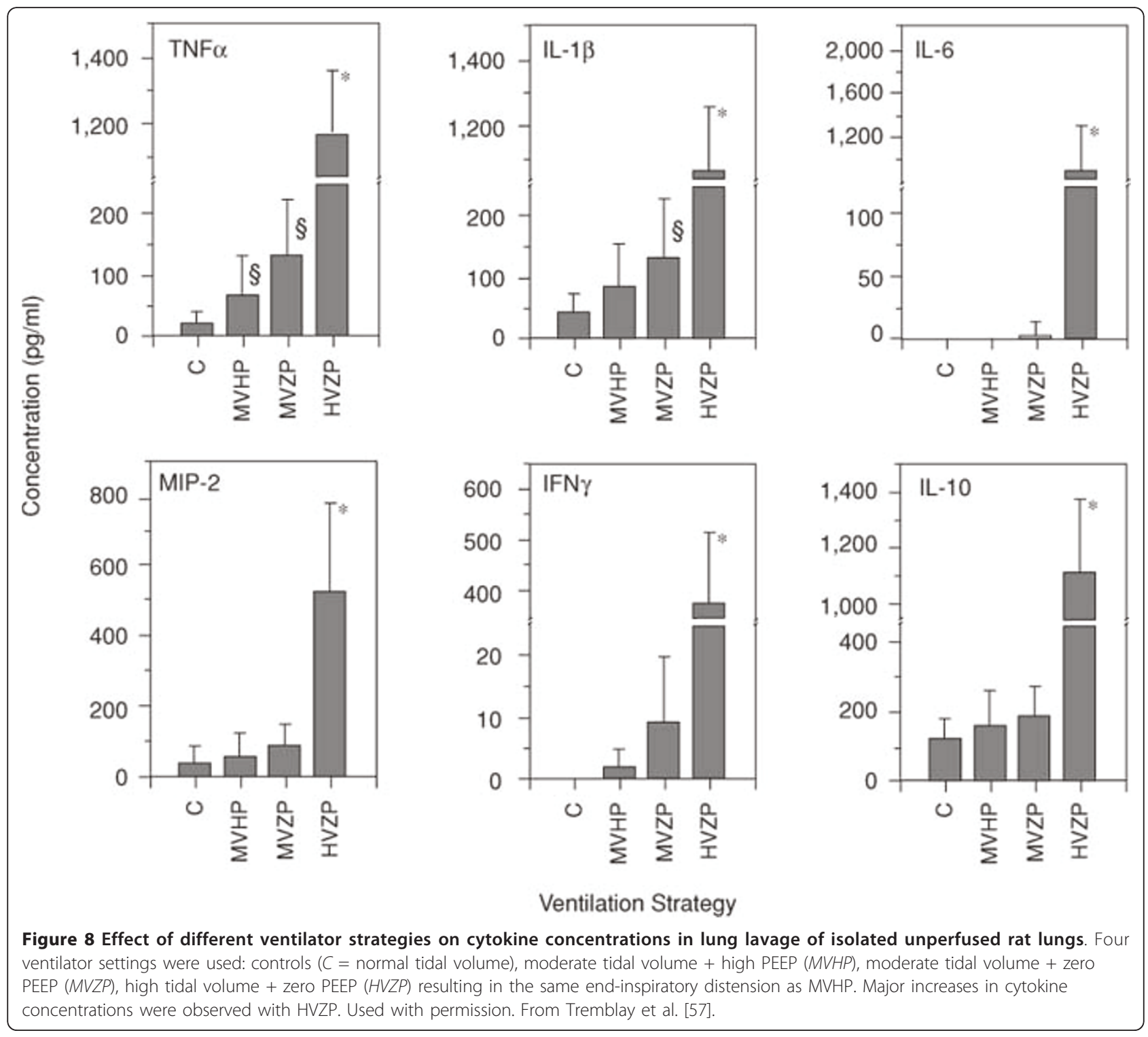




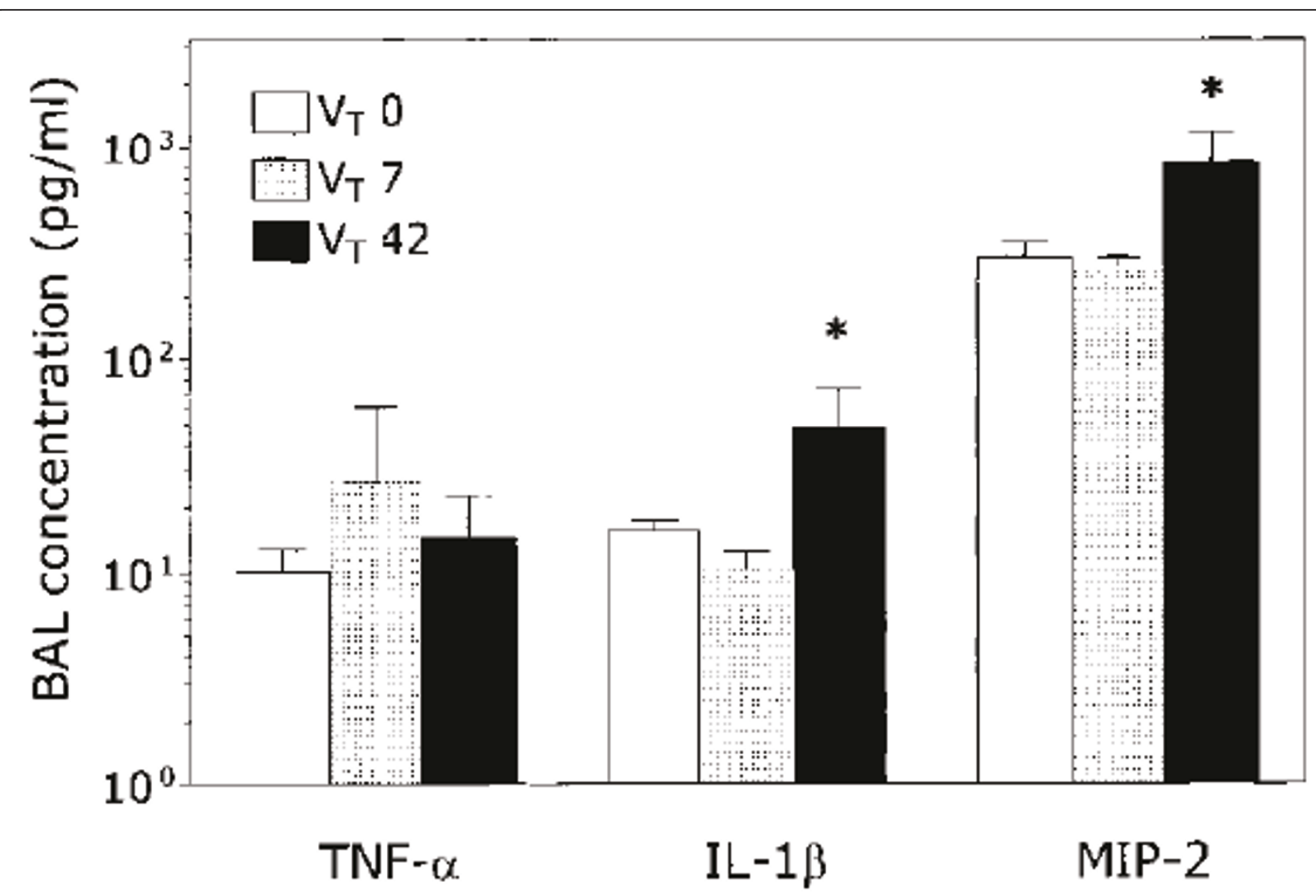

Figure 9 TNF- $\alpha$, IL-1 $\beta$, and MIP-2 concentrations in bronchoalveolar lavage fluid of isolated, nonperfused rat lungs maintained for $2 \mathrm{~h}$ in a statically inflated state at $7 \mathrm{~cm} \mathrm{H} \mathrm{H}_{2} \mathrm{O}$ airway pressure $\left(V_{T} O\right)$, ventilated with $7 \mathrm{~mL} / \mathrm{kg}$ tidal volume and $3 \mathrm{~cm} \mathrm{H}_{2} \mathrm{O}$ positive endexpiratory pressure $\left(V_{T} 7\right)$, or ventilated with $42 \mathrm{~mL} / \mathrm{kg} \mathrm{V}_{T}$ and zero end-expiratory pressure $\left(V_{T} \mathbf{4 2}\right)$. IL-1 $\beta$ and MIP-2 concentrations were slightly higher $\left({ }^{*} p<0.05\right)$ in the VT42 group. There was no difference in TNF- $\alpha$ concentration. Used with permission. From Ricard et al. [59].

"control" strategy (i.e., tidal volume of $11 \mathrm{~mL} / \mathrm{kg}$ and PEEP of $6 \mathrm{cmH}_{2} \mathrm{O}$ ) only $36 \mathrm{~h}$ after randomization [62]. However, this study was not designed to address whether these decreases were associated with improved clinical endpoints and the clinical meaning of these changes in cytokine levels remains elusive. Similarly, modest, although significant, differences were observed in the plasma levels of IL- 6 and IL- 8 in ARDS patients ventilated with 6 vs. $12 \mathrm{~mL} / \mathrm{kg}$ tidal volume [63]. In contrast, transiently changing ventilatory settings from a low tidal volume $(5 \mathrm{~mL} / \mathrm{kg})$-high PEEP $\left(15 \mathrm{~cm} \mathrm{H}_{2} \mathrm{O}\right)$ to a high tidal volume $(12 \mathrm{~mL} / \mathrm{kg})$-low PEEP $\left(5 \mathrm{~cm} \mathrm{H} \mathrm{H}_{2} \mathrm{O}\right)$ strategy in ALI patients led to an increase in plasma and bronchoalveolar lavage fluid levels of cytokines [64]. Intriguingly, most of these were anti-inflammatory cytokines (IL-1 receptor antagonist and IL-10), emphasizing that it remains unclear whether mechanical ventilation affects the balance of cytokines toward pro- or antiinflammation [65].

Finally, there is growing evidence that ventilator settings may localize or disperse proteinaceous lung edema or bacteria [66-68]. Indeed, ventilation with high tidal volume and no PEEP promoted contralateral bacterial seeding in a unilateral model of Pseudomonas aeruginosa pneumonia in rats [68]. In contrast, ventilation at the same endinspiratory pressure but with a high PEEP and thus a lower tidal volume prevented such contralateral dissemination. The potential for adverse ventilator patterns to disperse localized alveolar edema to the opposite lung was studied using scintigraphic methods [35]. A $99 \mathrm{~m}_{\text {Tc-labeled }}$ albumin solution was instilled in a distal airway and produced a zone of alveolar flooding that stayed localized during conventional ventilation. Ventilation with high endinspiratory pressure dispersed alveolar liquid in the lungs. This dispersion began almost immediately after highvolume ventilation was started and was likely the consequence of a convective movement induced by ventilation. Interestingly, PEEP application prevented this spread even when tidal volume was equivalent and thus end-inspiratory pressure higher (Figure 11). In heterogeneously ventilated lungs, fluid transfer may be propelled toward regions of normal compliance. PEEP may prevent fluid dispersion by avoiding lung collapse and stabilizing edema in the distal airways. 


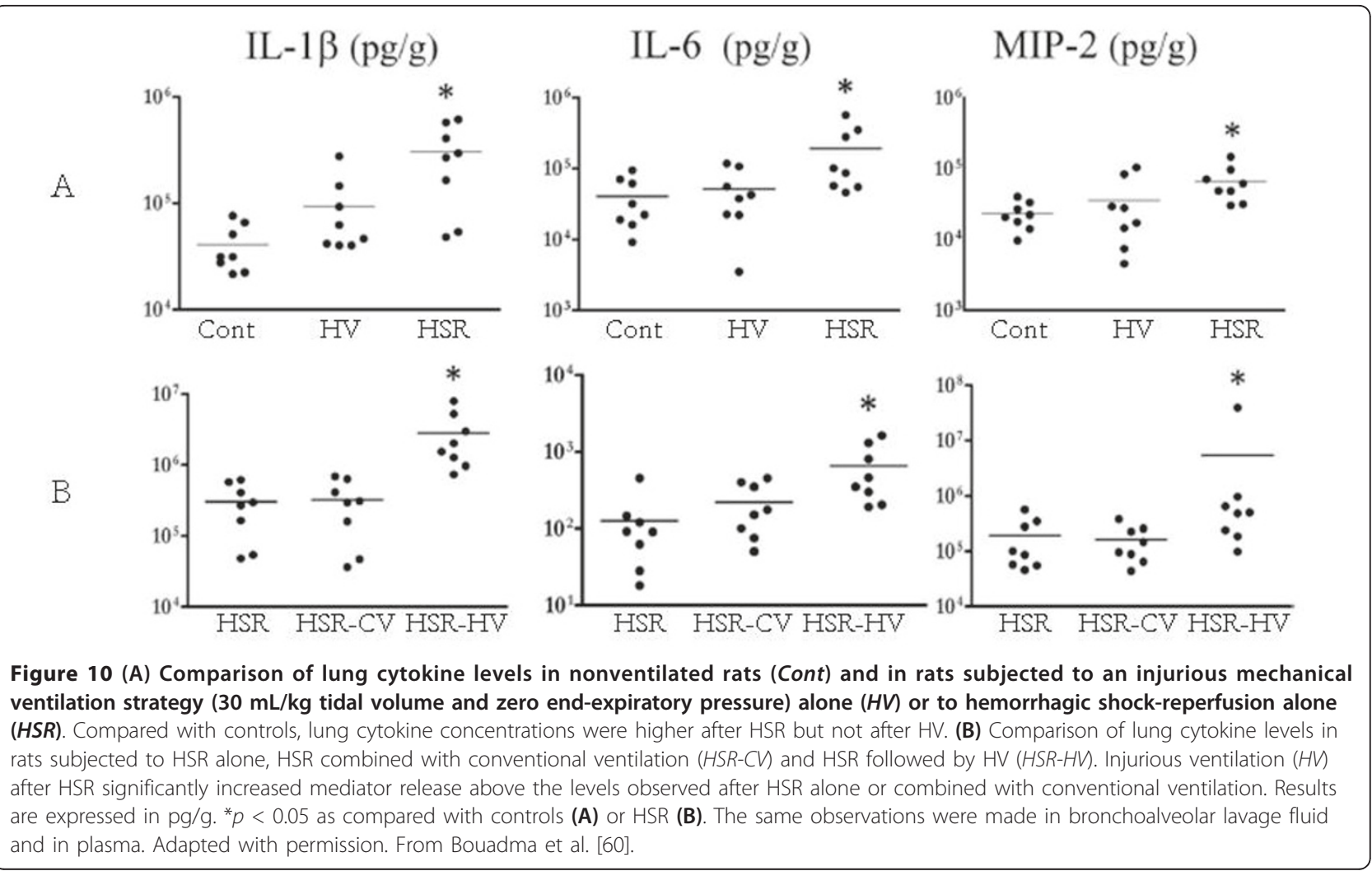

\section{Modulation of VILI}

Reducing the stress applied to the lungs by lowering tidal volume improved the survival of ARDS patients [3]. However, the mortality rate remains high, between 30 and $60 \%$ depending on the study $[2,69]$. Thus, a considerable amount of studies aiming at developing new ventilator strategies or pharmacological treatments of VILI have been published.

\section{Mechanical measures}

Despite promising experimental results that suggest that they could suppress air-liquid interfaces and allow for reopening of collapsed or liquid-filled areas, surfactant administration [70] and partial liquid ventilation with perfluorocarbons [71] have been abandoned since the negative results of clinical trials. Synthetic surfactant administration failed to improve oxygenation [72] and to improve lung mechanics [73] in ARDS patients. This could be related to the type of surfactant tested as another study using a natural surfactant in a pediatric population with acute lung injury was associated with increased survival [74]. Partial liquid ventilation with perfluorocarbons at both "high" $(20 \mathrm{~mL} / \mathrm{kg})$ and "low" $(10 \mathrm{~mL} / \mathrm{kg})$ doses did not improve outcome of ARDS patients [75]. Such negative results might have been anticipated from the results of experimental studies that had previously demonstrated that ventilator-induced pulmonary edema was aggravated in animals given such high doses of perfluorocarbons because they favored gas trapping in the distal lung [76].

Two randomized, controlled trials showed no effect of prone positioning on outcome of ARDS patients [77,78]. However, Mancebo et al. demonstrated that prone positioning was associated with a trend toward higher survival when administered early during the course of the disease and for as much as $20 \mathrm{~h}$ per day [79]. A recent meta-analysis found that prone positioning was associated with improved mortality in the most hypoxemic patients (i.e., having a $\mathrm{PaO}_{2} / \mathrm{FiO}_{2}$ ratio $<100 \mathrm{mmHg}$ ) [80]. These results are in keeping with experimental studies that evidenced that prone ventilation lessened the histological injury associated with high peak pressure ventilation in a dog model of oleic-acid lung injury [81]. These protective effects likely stem from a more homogenous distribution of ventilation associated with prone ventilation [82].

\section{Pharmacological treatments}

Numerous cell signaling pathways are involved in the pathophysiology of VILI. As such, hundreds of studies aiming at testing pharmacologic interventions during VILI have been published: 1) studies designed to modulate microvascular permeability using blockers of stretch-activated cation channels [83], beta-adrenergic 


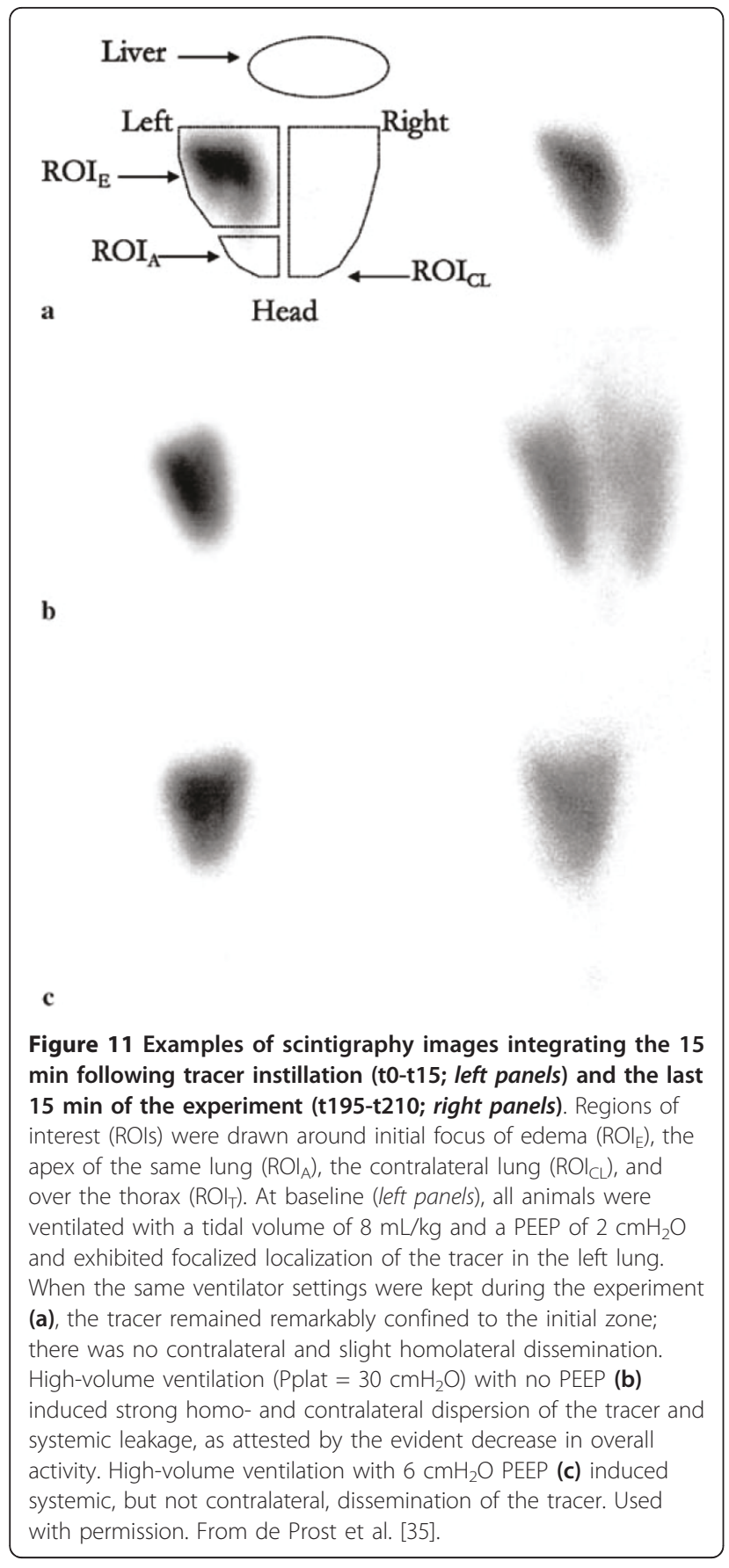

agonists [84], inhibitors of phosphotyrosine kinase [85], or reducing myosin light chain phosphorylation with adrenomedullin [86]; 2) studies testing the modulation of the imbalance between pro- and anti-inflammatory mediators in the lung. For instance, the administration of anti-TNF$\alpha$ antibody [87-89] and the inhibition of MIP-2 activity $[90,91]$ reduced neutrophilic infiltration and lung injury; and 3) studies modulating hormonal and metabolic pathways: inhibition of the renin-angiotensin system [92,93] and pretreatment with atorvastatin or simvastatin $[94,95]$ decreased alveolar-capillary barrier permeability and lung inflammation in experimental models of VILI. However, none of those pharmacological interventions has proven beneficial for the prevention and treatment of VILI in patients. Although it is probably illusory to believe that a single pharmacological intervention might be beneficial in patients, the description of those pathways illustrates the complexity of the cellular mechanisms involved in VILI.

\section{Clinical relevance of VILI}

As discussed earlier in this article, the prevention of ventilator-associated lung injury during treatment of ALI may theoretically stem from two approaches: 1) easing the strain [96] applied to diseased lungs through the reduction of tidal volume and therefore of endinspiratory lung volume (which may be evaluated indirectly by inspiratory plateau pressure); and 2) reducing the so-called atelectrauma via an adequate use of PEEP. Whereas the first concept, which is undisputed on physiological grounds, received a resounding illustration with the demonstration of an improved prognosis by a simple reduction of tidal volume in ARDS patients [3], things are far less clear regarding the second. Indeed, as explained above, the concept of repetitive opening and closure or distal airspaces and the putative low lung volume lesions related to insufficient PEEP levels remains debated. This uncertainty formed the basis of three high-quality, independent, randomized, controlled studies $[2,53,54]$, which all failed to demonstrate improved survival with a high PEEP strategy. Although a meta-analysis of these trials showed a reduction of mortality using higher PEEP levels in the most severe population [97], this does not constitute a definite proof but rather a hypothesis that would require another well-conducted, randomized trial to be confirmed. Moreover, the marked heterogeneity of ventilator protocols among these three studies (with resulting considerable differences in plateau pressures between one study [54] and the others [2,53]) casts some doubt on the physiological rationale for this meta-analysis. Interestingly, a recent study using positron emission tomography imaging in ARDS patients to quantify lung metabolism, a surrogate of lung inflammation, showed that lung regions undergoing cyclic recruitment-derecruitment did not exhibit higher metabolism than those continuously collapsed throughout the respiratory cycle, thus questioning the concept of low lung volume injury [98].

\section{Conclusions}

Few experimental concepts have led to dramatic changes in clinical practices as the concept of VILI did. The understanding that end-inspiratory distension is the main determinant of VILI led to the reduction of tidal 
volume and improved the survival of ARDS patients. Yet, whether tidal volume should be set at $6 \mathrm{~mL} / \mathrm{kg}$ in all patients remains unsettled [99], and there is currently no bedside tool that allows an accurate assessment of the aerated lung volume and thus no way to tailor tidal volume routinely. Rather than sticking to arbitrarily fixed approaches, clinicians should tailor mechanical ventilation according to patient's individual characteristics, including close monitoring of plateau pressure and maybe PEEP titration guided by esophageal pressure monitoring [100]. In addition, opinion leaders should strive to convince clinicians not to use excessive tidal volume, which is still unfortunately the case [101]. Indeed, two epidemiological studies suggested an association between ventilator settings (i.e., use of a tidal volume $>6 \mathrm{~mL} / \mathrm{kg}$ or 700 $\mathrm{mL}$ [102] and plateau pressure $>30 \mathrm{~cm} \mathrm{H}_{2} \mathrm{O}$ [103]) and the development of ARDS in mechanically ventilated patients who did not meet ARDS criteria upon hospital admission. Similarly, a relationship between the use of large tidal volumes and postoperative respiratory failure has been established after mechanical ventilation in patients undergoing a pneumonectomy, suggesting that ventilation does not need to be protracted to be deleterious [104]. Even though the tidal volume to be used in patients with so-called normal lungs has not been defined yet, these studies suggest that protective ventilator settings could prevent the development or ARDS, particularly when a systemic insult is associated.

The story of VILI and its clinical correlates may be viewed as a success of applied physiology $[105,106]$. Indeed, based on sound physiology, physicians had started to reduce tidal volume long before this strategy was proved by randomized, controlled trials [5,107]. The considerable improvement in survival of ARDS patients with a simple and low-cost physiologic approach is at striking contrast with the failure of many randomized trials of expensive drugs to improve the prognosis of critically ill patients $[105,106]$. Nevertheless, many questions persist and VILI will likely not soon be out of the spotlight.

\section{Abbreviations}

ANTU: a-naphthylthiourea; ARDS: acute respiratory distress syndrome; LIP: lower inflection point; PEEP: positive end-expiratory pressure; PV: pressurevolume; UIP: upper inflection point; VILI: ventilator-induced lung injury.

\section{Author details}

'Assistance Publique - Hôpitaux de Paris, Hôpital Henri Mondor, Service de Réanimation Médicale, 51, Avenue de Tassigny, 94010, Créteil, France 2Université Paris-Diderot and PRES Sorbonne Paris Cité, Site Xavier Bichat, 75018 Paris, France ${ }^{3}$ Assistance Publique - Hôpitaux de Paris, Hôpital Louis Mourier, Service de Réanimation Médicale, F-92700, 178, rue des Renouillers 92701 Colombes Cedex, France ${ }^{4}$ INSERM U722, F-75018 Paris, France

\section{Authors' contributions}

NDP and DD drafted the manuscript, and JDR and GS revised the manuscript.

\section{Competing interests}

The authors declare that they have no competing interests.

Received: 25 June 2011 Accepted: 23 July 2011 Published: 23 July 2011

\section{References}

1. Zapol WM, Snider MT, Hill JD, et al: Extracorporeal membrane oxygenation in severe acute respiratory failure. JAMA 1979, 242:2193-2196.

2. Mercat A, Richard JC, Vielle B, Jaber S, Osman D, Diehl JL, Lefrant JY, Prat G, Richecoeur J, Nieszkowska A, et al: Positive end-expiratory pressure setting in adults with acute lung injury and acute respiratory distress syndrome: a randomized controlled trial. JAMA 2008, 299:646-655.

3. Ventilation with lower tidal volumes as compared with traditional tidal volumes for acute lung injury and the acute respiratory distress syndrome. The Acute Respiratory Distress Syndrome Network. N Engl $J$ Med 2000, 342:1301-1308.

4. Hickling KG, Henderson SJ, Jackson R: Low mortality associated with low volume pressure limited ventilation with permissive hypercapnia in severe adult respiratory distress syndrome. Intensive Care Med 1990, 16:372-377.

5. Jardin F, Fellahi JL, Beauchet A, Vieillard-Baron A, Loubieres Y, Page B Improved prognosis of acute respiratory distress syndrome 15 years on. Intensive Care Med 1999, 25:936-941.

6. Webb HH, Tierney DF: Experimental pulmonary edema due to intermittent positive pressure ventilation with high inflation pressures. Protection by positive end-expiratory pressure. Am Rev Respir Dis 1974, 110:556-565.

7. Parker JC, Townsley MI, Rippe B, Taylor AE, Thigpen J: Increased microvascular permeability in dog lungs due to high airway pressures. $J$ Appl Physiol 1984, 57:1809-1816.

8. Dreyfuss D, Basset G, Soler P, Saumon G: Intermittent positive-pressure hyperventilation with high inflation pressures produces pulmonary microvascular injury in rats. Am Rev Respir Dis 1985, 132:880-884.

9. Argiras EP, Blakeley CR, Dunnill MS, Otremski S, Sykes MK: High peep decreases hyaline membrane formation in surfactant deficient lungs. $B r$ J Anaesth 1987, 59:1278-1285.

10. Bilek AM, Dee KC, Gaver DP: Mechanisms of surface-tension-induced epithelial cell damage in a model of pulmonary airway reopening. J Appl Physiol 2003, 94:770-783.

11. Muscedere JG, Mullen JBM, Gan K, Bryan AC, Slutsky AS: Tidal ventilation at low airway pressures can augment lung injury. Am J Respir Crit Care Med 1994, 149:1327-1334.

12. Ashbaugh $D G$, Bigelow DB, Petty $T L$, Levine BE: Acute respiratory distress in adults. Lancet 1967, 2:319-323.

13. Mead J, Takishima T, Leith D: Stress distribution in lungs: a model of pulmonary elasticity. J Appl Physiol 1970, 28:596-608

14. Tierney DF: Ventilator-induced lung injury occurs in rats, but does it occur in humans? Am J Respir Crit Care Med 2003, 168:1414-1415.

15. Dreyfuss D, Saumon G: Ventilator-induced lung injury: lessons from experimental studies (State of the Art). Am J Respir Crit Care Med 1998, 157:1-30.

16. Parker JC, Hernandez LA, Longenecker GL, Peevy K, Johnson W: Lung edema caused by high peak inspiratory pressures in dogs. Role of increased microvascular filtration pressure and permeability. Am Rev Respir Dis 1990, 142:321-328.

17. Howell JBL, Permutt S, Proctor DF, Riley RL: Effect of inflation of the lung on different parts of pulmonary vascular bed. J Appl Physiol 1961, 16:71-76.

18. Benjamin JJ, Murtagh PS, Proctor DF, Menkes HA, Permutt S: Pulmonary vascular interdependence in excised dog lobes. J Appl Physiol 1974, 37:887-894.

19. Faridy EE, Permutt S, Riley RL: Effect of ventilation on surface forces in excised dogs' lungs. J Appl Physiol 1966, 21:1453-1462.

20. McClenahan JB, Urtnowski A: Effect of ventilation on surfactant, and its turnover rate. J Appl Physiol 1967, 23:215-220. 
21. Veldhuizen RA, Tremblay LN, Govindarajan A, van Rozendaal BA Haagsman HP, Slutsky AS: Pulmonary surfactant is altered during mechanical ventilation of isolated rat lung. Crit Care Med 2000, 28:2545-2551.

22. Pattle RE: Properties, function and origin of the alveolar lining layer. Nature (Lond) 1955, 175:1125-1126.

23. Clements JA: Pulmonary edema and permeability of alveolar membranes. Arch Environ Health 1961, 2:280-283.

24. Albert RK, Lakshminarayan S, Hildebrandt J, Kirk W, Butler J: Increased surface tension favors pulmonary edema formation in anesthetized dogs' lungs. J Clin Invest 1979, 63:1015-1018

25. Egan EA, Nelson RM, Olver RE: Lung inflation and alveolar permeability to non-electrolytes in the adult sheep in vivo. J Physiol (Lond) 1976, 260:409-424.

26. Egan EA: Response of alveolar epithelial solute permeability to changes in lung inflation. J Appl Physiol 1980, 49:1032-1036.

27. Guyton AC, Lindsey AW: Effect of elevated left atrial pressure and decreased plasma protein concentration on the development of pulmonary edema. Circ Res 1959, 7:649-653.

28. Pingleton SK: Complications of acute respiratory failure (State of the Art). Am Rev Respir Dis 1988, 137:1463-1493.

29. Dreyfuss D, Soler P, Basset G, Saumon G: High inflation pressure pulmonary edema. Respective effects of high airway pressure, high tidal volume, and positive end-expiratory pressure. Am Rev Respir Dis 1988, 137:1159-1164.

30. Hernandez LA, Peevy KJ, Moise AA, Parker JC: Chest wall restriction limits high airway pressure-induced lung injury in young rabbits. J Appl Physiol 1989, 66:2364-2368.

31. Carlton DP, Cummings JJ, Scheerer RG, Poulain FR, Bland RD: Lung overexpansion increases pulmonary microvascular protein permeability in young lambs. J Appl Physiol 1990, 69:577-583.

32. de Prost N, Dreyfuss D, Saumon G: Evaluation of two-way protein fluxes across the alveolo-capillary membrane by scintigraphy in rats: effect of lung inflation. J Appl Physiol 2007, 102:794-802.

33. Dreyfuss D, Saumon G: Role of tidal volume, FRC and end-inspiratory volume in the development of pulmonary edema following mechanical ventilation. Am Rev Respir Dis 1993, 148:1194-1203.

34. Corbridge TC, Wood LDH, Crawford GP, Chudoba MJ, Yanos J, Sznadjer J: Adverse effects of large tidal volume and low PEEP in canine acid aspiration. Am Rev Respir Dis 1990, 142:311-315.

35. de Prost N, Roux D, Dreyfuss D, Ricard JD, Le Guludec D, Saumon G: Alveolar edema dispersion and alveolar protein permeability during high volume ventilation: effect of positive end-expiratory pressure. Intensive Care Med 2007, 33:711-717.

36. Kolobow T, Moretti MP, Fumagalli $R$, Mascheroni $D$, Prato $P$, Chen $V$, Joris M: Severe impairment in lung function induced by high peak airway pressure during mechanical ventilation. Am Rev Respir Dis 1987, 135:312-315.

37. Hernandez LA, Coker PJ, May S, Thompson AL, Parker JC: Mechanical ventilation increases microvascular permeability in oleic injured lungs. J Appl Physiol 1990, 69:2057-2061.

38. Dreyfuss D, Soler P, Saumon G: Mechanical ventilation-induced pulmonary edema. Interactions with previous lung alterations. Am J Respir Crit Care Med 1995, 151:1568-1575.

39. Gattinoni L, Pesanti A, Avalli L, Rossi F, Bombino M: Pressure-volume curves of total respiratory system in acute respiratory failure. Computed tomographic scan study. Am Rev Respir Dis 1987, 136:730-736.

40. Gattinoni L, Pesenti A: The concept of "baby lung.". Intensive Care Med 2005, 31:776-784

41. Dambrosio M, Roupie E, Mollet JJ, Anglade MC, Vasile N, Lemaire F, Brochard L: Effects of PEEP and different tidal volumes on alveolar recruitment and hyperinflation. Anesthesiology 1997, 87:497-503.

42. Roupie E, Dambrosio M, Servillo G, Mentec H, El Atrous S, Beydon L, BrunBruisson C, Lemaire F, Brochard L: Titration of tidal volume and induced hypercapnia in acute respiratory distress syndrome. Am J Respir Crit Care Med 1995, 152:121-128.

43. Martin-Lefevre L, Ricard JD, Roupie E, Dreyfuss D, Saumon G: Significance of the changes in the respiratory system pressure-volume curve during acute lung injury in rats. Am J Respir Crit Care Med 2001, 164:627-632

44. Matamis D, Lemaire F, Harf A, Brun-Buisson C, Ansquer JC, Atlan G: Total respiratory pressure-volume curves in the adult respiratory distress syndrome. Chest 1984, 86:58-66.
45. Suter PM, Fairley B, Isenberg MD: Optimum end-expiratory airway pressure in patients with acute pulmonary failure. N Engl J Med 1975 292:284-289.

46. Sandhar BK, Niblett DJ, Argiras EP, Dunnill MS, Sykes MK: Effects of positive end-expiratory pressure on hyaline membrane formation in a rabbit model of the neonatal respiratory distress syndrome. Intensive Care Med 1988, 14:538-546.

47. Sohma A, Brampton WJ, Dunnill MS, Sykes MK: Effect of ventilation with positive end-expiratory pressure on the development of lung damage in experimental acid aspiration pneumonia in the rabbit. Intensive Care Med 1992, 18:112-117.

48. Lichtwarck-Aschoff M, Mols G, Hedlund AJ, Kessler V, Markström AM, Guttmann J, Hedenstierna G, Sjöstrand UH: Compliance is nonlinear over VT irrespective of PEEP level in surfactant-depleted piglets. Am J Respir Crit Care Med 2000, 162:2125-2133.

49. Tsuno K, Miura K, Takey M, Kolobow T, Morioka T: Histopathologic pulmonary changes from mechanical ventilation at high peak airway pressures. Am Rev Respir Dis 1991, 143:1115-1120.

50. Hubmayr RD: Perspective on lung injury and recruitment: a skeptical look at the opening and collapse story. Am J Respir Crit Care Med 2002, 165:1647-1653.

51. Tremblay LN, Slutsky AS: Ventilator-induced lung injury: from the bench to the bedside. Intensive Care Med 2006, 32:24-33.

52. Martynowicz MA, Walters BJ, Hubmayr RD: Mechanisms of recruitment in oleic acid-injured lungs. J Appl Physiol 2001, 90:1744-1753.

53. Higher versus lower positive end-expiratory pressures in patients with the acute respiratory distress syndrome. N Engl J Med 2004, 351:327-336

54. Meade MO, Cook DJ, Guyatt GH, Slutsky AS, Arabi YM, Cooper DJ, Davies AR, Hand LE, Zhou Q, Thabane L, et al: Ventilation strategy using low tidal volumes, recruitment maneuvers, and high positive endexpiratory pressure for acute lung injury and acute respiratory distress syndrome: a randomized controlled trial. JAMA 2008, 299:637-645.

55. Markos J, Doerschuk CM, English D, Wiggs BR, Hogg JC: Effect of positive end-expiratory pressure on leukocyte transit in rabbit lungs. $J$ Appl Physiol 1993, 74:2627-2633.

56. Kawano T, Mori S, Cybulsky M, Burger R, Ballin A, Cutz E, Bryan AC: Effect of granulocyte depletion in a ventilated surfactant-depleted lung. J Appl Physiol 1987, 62:27-33.

57. Tremblay L, Valenza F, Ribeiro SP, Li J, Slutsky AS: Injurious ventilatory strategies increase cytokines and c-fos m-RNA expression in an isolated rat lung model. J Clin Invest 1997, 99:944-952

58. Dreyfuss D, Ricard JD, Saumon G: On the physiologic and clinical relevance of lung-borne cytokines during ventilator-induced lung injury. Am J Respir Crit Care Med 2003, 167:1467-1471.

59. Ricard JD, Dreyfuss D, Saumon G: Production of inflammatory cytokines in ventilator-induced lung injury: a reappraisal. Am J Respir Crit Care Med 2001, 163:1176-1180.

60. Bouadma L, Dreyfuss D, Ricard JD, Martet G, Saumon G: Mechanical ventilation and hemorrhagic shock-resuscitation interact to increase inflammatory cytokine release in rats. Crit Care Med 2007, 35:2601-2606.

61. Bouadma L, Schortgen F, Ricard J, Martet G, Dreyfuss D, Saumon G: Ventilation strategy affects cytokine release after mesenteric ischemiareperfusion in rats. Crit Care Med 2004, 32:1563-1569.

62. Ranieri VM, Giunta F, Suter PM, Slutsky AS: Mechanical ventilation as a mediator of multisystem organ failure in acute respiratory distress syndrome. JAMA 2000, 284:43-44.

63. Parsons PE, Eisner MD, Thompson BT, Matthay MA, Ancukiewicz M, Bernard GR, Wheeler AP: Lower tidal volume ventilation and plasma cytokine markers of inflammation in patients with acute lung injury. Crit Care Med 2005, 33:1-6.

64. Stuber F, Wrigge H, Schroeder S, Wetegrove S, Zinserling J, Hoeft A Putensen C: Kinetic and reversibility of mechanical ventilation-associated pulmonary and systemic inflammatory response in patients with acute lung injury. Intensive Care Med 2002, 28:834-841.

65. Pugin J: Is the ventilator responsible for lung and systemic inflammation? Intensive Care Med 2002, 28:817-819.

66. Nahum A, Hoyt J, Schmitz L, Moody J, Shapiro R, Marini JJ: Effect of mechanical ventilation strategy on dissemination of intratracheally instilled Escherichia coli in dogs. Crit Care Med 1997, 25:1733-1743. 
67. Verbrugge S, Sorm V, van 't Veen A, Mouton J, Gommers D, Lachmann B: Lung overinflation without positive end-expiratory pressure promotes bacteremia after experimental Klebsiella pneumoniae inoculation. Intensive Care Med 1998, 24:172-177.

68. Schortgen F, Bouadma L, Joly-Guillou ML, Ricard JD, Dreyfuss D, Saumon G: Infectious and inflammatory dissemination are affected by ventilation strategy in rats with unilateral pneumonia. Intensive Care Med 2004, 30:693-701.

69. Brun-Buisson C, Minelli C, Bertolini G, Brazzi L, Pimentel J, Lewandowski K, Bion J, Romand JA, Villar J, Thorsteinsson A, et al: Epidemiology and outcome of acute lung injury in European intensive care units. Results from the ALIVE study. Intensive Care Med 2004, 30:51-61.

70. Verbrugge SJ, Vazquez de Anda G, Gommers D, Neggers SJ, Sorm V, Bohm SH, Lachmann B: Exogenous surfactant preserves lung function and reduces alveolar Evans blue dye influx in a rat model of ventilationinduced lung injury. Anesthesiology 1998, 89:467-474.

71. Lachmann B, Fraterman A, Verbrugge SJC: Physiological basis of mechanical ventilation. In Liquid ventilation. Edited by: Dekker M. New York; 1998:

72. Anzuetto A, Baughman R, Guntupalli KK, Weg JG, Wiedemann HP, Raventos AA, Lemaire F, Long W, Zacardelli DS, Pattishall EN: Aerosolized surfactant in adults with sepsis-induced acute respiratory distress syndrome. N Engl J Med 1996, 334:1417-1421.

73. Spragg RG, Lewis JF, Walmrath $H D$, Johannigman J, Bellingan G, Laterre PF, Witte MC, Richards GA, Rippin G, Rathgeb F, et al: Effect of recombinant surfactant protein $\mathrm{C}$-based surfactant on the acute respiratory distress syndrome. N Engl J Med 2004, 351:884-892.

74. Willson DF, Thomas NJ, Markovitz BP, Bauman LA, DiCarlo JV, Pon S, Jacobs BR, Jefferson LS, Conaway MR, Egan EA: Effect of exogenous surfactant (calfactant) in pediatric acute lung injury: a randomized controlled trial. JAMA 2005, 293:470-476.

75. Kacmarek RM, Wiedemann HP, Lavin PT, Wedel MK, Tutuncu AS, Slutsky AS: Partial liquid ventilation in adult patients with the acute respiratory distress syndrome. Am J Respir Crit Care Med 2006, 173:882-889.

76. Ricard JD, Dreyfuss D, Laissy JP, Saumon G: Dose-response effect of perfluorocarbon administration on lung microvascular permeability in rats. Am J Respir Crit Care Med 2003, 168:1378-1382.

77. Guerin C, Gaillard S, Lemasson S, Ayzac L, Girard R, Beuret P, Palmier B, Le QV, Sirodot M, Rosselli S, et al: Effects of systematic prone positioning in hypoxemic acute respiratory failure: a randomized controlled trial. JAMA 2004, 292:2379-2387.

78. Taccone P, Pesenti A, Latini R, Polli F, Vagginelli F, Mietto C, Caspani L, Raimondi F, Bordone $G$, lapichino $G$, et al: Prone positioning in patients with moderate and severe acute respiratory distress syndrome: a randomized controlled trial. JAMA 2009, 302:1977-1984.

79. Mancebo J, Fernandez R, Blanch L, Rialp G, Gordo F, Ferrer M, Rodriguez F, Garro P, Ricart P, Vallverdu I, et al: A multicenter trial of prolonged prone ventilation in severe acute respiratory distress syndrome. Am J Respir Crit Care Med 2006, 173:1233-1239.

80. Sud S, Friedrich JO, Taccone P, Polli F, Adhikari NK, Latini R, Pesenti A, Guerin C, Mancebo J, Curley MA, et al: Prone ventilation reduces mortality in patients with acute respiratory failure and severe hypoxemia: systematic review and meta-analysis. Intensive Care Med 2010, 36:585-599.

81. Broccard AF, Shapiro RS, Schmitz LL, Ravenscraft SA, Marini JJ: Influence of prone position on the extent and distribution of lung injury in a high tidal volume oleic acid model of acute respiratory distress syndrome. Crit Care Med 1997, 25:16-27.

82. Richter T, Bellani G, Scott Harris R, Vidal Melo MF, Winkler T, Venegas JG, Musch G: Effect of prone position on regional shunt, aeration, and perfusion in experimental acute lung injury. Am J Respir Crit Care Med 2005, 172:480-487

83. Parker JC, Ivey CL, Tucker JA: Gadolinium prevents high airway pressureinduced permeability increases in isolated rat lungs. J Appl Physiol 1998, 84:1113-1118.

84. de Prost N, Dreyfuss D, Ricard JD, Saumon G: Terbutaline lessens protein fluxes across the alveolo-capillary barrier during high-volume ventilation. Intensive Care Med 2008, 34:763-770.
85. Parker JC: Inhibitors of myosin light chain kinase and phosphodiesterase reduce ventilator-induced lung injury. J Appl Physiol 2000, 89:2241-2248.

86. Muller HC, Witzenrath M, Tschernig T, Gutbier B, Hippenstiel S, Santel A, Suttorp N, Rosseau S: Adrenomedullin attenuates ventilator-induced lung injury in mice. Thorax 2010, 65:1077-1084.

87. Wilson MR, Choudhury S, Takata M: Pulmonary inflammation induced by high-stretch ventilation is mediated by tumor necrosis factor signaling in mice. Am J Physiol Lung Cell Mol Physiol 2005, 288:L599-607.

88. Guery BP, Welsh DA, Viget NB, Robriquet L, Fialdes P, Mason CM, Beaucaire G, Bagby GJ, Neviere R: Ventilation-induced lung injury is associated with an increase in gut permeability. Shock 2003, 19:559-563.

89. Imai Y, Kawano T, Iwamoto S, Nakagawa S, Takata M, Miyasaka K: Intratracheal anti-tumor necrosis factor-alpha antibody attenuates ventilator-induced lung injury in rabbits. J App/ Physiol 1999, 87:510-515.

90. Quinn DA, Moufarrej RK, Volokhov A, Hales CA: Interactions of lung stretch, hyperoxia, and MIP-2 production in ventilator-induced lung injury. J Appl Physiol 2002, 93:517-525.

91. Belperio JA, Keane MP, Burdick MD, Londhe V, Xue YY, Li K, Phillips RJ Strieter RM: Critical role for CXCR2 and CXCR2 ligands during the pathogenesis of ventilator-induced lung injury. J Clin Invest 2002, 110:1703-1716.

92. Jerng JS, Hsu YC, Wu HD, Pan HZ, Wang HC, Shun CT, Yu CJ, Yang PC: Role of the renin-angiotensin system in ventilator-induced lung injury: an in vivo study in a rat model. Thorax 2007, 62:527-535.

93. Jiang JS, Wang LF, Chou HC, Chen CM: Angiotensin-converting enzyme inhibitor captopril attenuates ventilator-induced lung injury in rats. $J$ Appl Physiol 2007, 102:2098-2103.

94. Siempos II, Maniatis NA, Kopterides P, Magkou C, Glynos C, Roussos C, Armaganidis $A$ : Pretreatment with atorvastatin attenuates lung injury caused by high-stretch mechanical ventilation in an isolated rabbit lung model. Crit Care Med 2010, 38:1321-1328.

95. Muller HC, Hellwig K, Rosseau S, Tschernig T, Schmiedl A, Gutbier B, Schmeck B, Hippenstiel S, Peters $H$, Morawietz L, et al: Simvastatin attenuates ventilator-induced lung injury in mice. Crit Care 2010, 14:R143.

96. Chiumello D, Carlesso E, Cadringher P, Caironi P, Valenza F, Polli F, Tallarini F, Cozzi P, Cressoni M, Colombo A, et al: Lung stress and strain during mechanical ventilation for acute respiratory distress syndrome. Am J Respir Crit Care Med 2008, 178:346-355.

97. Briel M, Meade M, Mercat A, Brower RG, Talmor D, Walter SD, Slutsky AS, Pullenayegum E, Zhou Q, Cook D, et al: Higher vs lower positive endexpiratory pressure in patients with acute lung injury and acute respiratory distress syndrome: systematic review and meta-analysis JAMA 2010, 303:865-873.

98. Bellani G, Guerra L, Musch G, Zanella A, Patroniti N, Mauri T, Messa C, Pesenti $A$ : Lung regional metabolic activity and gas volume changes induced by tidal ventilation in patients with acute lung injury. Am J Respir Crit Care Med 2011, 183:1193-1199.

99. Deans K, Minneci PC, Cui X, Banks SM, Natanson C, Eichacker PQ: Mechanical ventilation in ARDS: one size does not fit all. Crit Care Med 2005, 33:1141-1143.

100. Talmor D, Sarge T, Malhotra A, O'Donnell CR, Ritz R, Lisbon A, Novack V, Loring SH: Mechanical ventilation guided by esophageal pressure in acute lung injury. N Engl J Med 2008, 359:2095-2104.

101. Dreyfuss D: Acute lung injury and mechanical ventilation: need for quality assurance. Crit Care Med 2004, 32:1960-1961.

102. Gajic O, Dara SI, Mendez JL, Adesanya AO, Festic E, Caples SM, Rana R, St Sauver JL, Lymp JF, Afessa B, Hubmayr RD: Ventilator-associated lung injury in patients without acute lung injury at the onset of mechanical ventilation. Crit Care Med 2004, 32:1817-1824.

103. Gajic O, Frutos-Vivar F, Esteban A, Hubmayr RD, Anzueto A: Ventilator settings as a risk factor for acute respiratory distress syndrome in mechanically ventilated patients. Intensive Care Med 2005, 31:922-926.

104. Fernandez-Perez ER, Keegan MT, Brown DR, Hubmayr RD, Gajic O: Intraoperative tidal volume as a risk factor for respiratory failure after pneumonectomy. Anesthesiology 2006, 105:14-18.

105. Dreyfuss D, Saumon G: Evidence-based medicine or fuzzy logic: what is best for ARDS management? Intensive Care Med 2002, 28:230-234. 
106. Dreyfuss D: Is it better to consent to an RCT or to care?

Muetadeltaepsilonnu alphagammaalphanu ("nothing in excess").

Intensive Care Med 2004, 31:345-355.

107. Esteban A, Anzueto A, Frutos F, Alia I, Brochard L, Stewart TE, Benito S,

Epstein SK, Apezteguia C, Nightingale P, et al: Characteristics and

outcomes in adult patients receiving mechanical ventilation: a 28-day

international study. JAMA 2002, 287:345-355.

doi:10.1186/2110-5820-1-28

Cite this article as: de Prost et al.: Ventilator-induced lung injury:

historical perspectives and clinical implications. Annals of Intensive Care 2011 1:28.

\section{Submit your manuscript to a SpringerOpen ${ }^{\circ}$ journal and benefit from:}

- Convenient online submission

- Rigorous peer review

- Immediate publication on acceptance

- Open access: articles freely available online

- High visibility within the field

- Retaining the copyright to your article

Submit your next manuscript at $\gg$ springeropen.com 